\title{
THE EFFECT OF ENTREPRENEURIAL LEADERSHIP ON ORGANIZATIONAL PERFORMANCE: LITERATURE REVIEW
}

\author{
Erna Herlina $^{1^{*}}$, Martinus Tukiran ${ }^{2}$, Syaiful Anwar ${ }^{3}$ \\ ${ }^{1,2,3}$ Universitas Pakuan, Indonesia \\ E-mail: eherlina20@gmail.com
}

\begin{abstract}
In a competitive, dynamic, complex and uncertain business environment as it is today, a leadership type is needed that can play an important role for the survival, success, and growth of the organization. This paper aims to review the influence of entrepreneurial leadership on organizational performance in terms of three hierarchies: individuals, groups/teams, and the organization as a whole. According to the findings of the review, entrepreneurial leadership has a major impact on the individual performance of employees and teams, especially in terms of creativity and creative behavior. Entrepreneurial leadership has a significant effect on overall organizational performance both in financial and non-financial dimensions.
\end{abstract}

Keywords: Entrepreneurial Leadership, Employee Performance, Organizational Performance.

\section{INTRODUCTION}

Leadership is the process of influencing employees to work towards achieving organizational goals. Therefore, leadership is an important factor that contributes to organizational success (Lussier \& Hendon, 2019). Each leader has their own style of influencing subordinates. Robbins and Judge (2017) divide leadership styles into three, namely charismatic, transformational, and transactional. Different leadership styles have varying effects on the overall effectiveness or performance of the organization (Wahab et al., 2016).

Studies on the relationship between leadership style and organizational behavior have been carried out for a long time. Most of these studies discuss transformational leadership styles and transactional leadership styles (Sani et al., 2018). Currently, a new paradigm is developing regarding leadership style and its relevance to organizational behavior that supports business growth and sustainable innovation where the leadership model is referred to as entrepreneurial leadership (Rutan, 2019).

An effective leader is needed in today's dynamic, complicated and uncertain business competition climate which can contribute significantly to the survival, success and expansion of the organization ( $\mathrm{Li}$ et al., 2020). Experts introduce entrepreneurial leadership as a new leadership theory to address dynamic changes in the $21^{\text {st }}$ century (Mehmood et al., 2020). The entrepreneurial leadership style is a relatively new and modern type of leadership characterized by a combination of leadership characteristics and an entrepreneurial spirit (Esmer \& Dayi, 2017). Basically entrepreneurial leadership is more like a transformational leadership style than a transactional leadership style but there are some basic differences (Paladan, 2015).

This type of leadership has received more attention from experts and practitioners because of its importance in increasing competitiveness, success and growth (Bagheri \& 
Harrison, 2020). Research findings indicate that entrepreneurial leadership is an important factor in improving organizational performance in a volatile and competitive environment (Harrison et al., 2019). This leadership can be applied to all organizations regardless of the size of the organization (Ranjan, 2018) both in business organizations (profit) and non-profit organizations (Arifin \& Gunawan, 2020). However, there are differences between the entrepreneurial leadership visions of nonprofit organizations and business where the most distinguishing factors are inspiration, realism, conservatism, and flexibility (Ruvio et al., 2010).

\section{THEORETICAL BASIS}

\subsection{Entrepreneurial Leadership}

Entrepreneurial leadership is a combination of entrepreneurial-oriented leadership and entrepreneurial management (Gupta et al., 2004). Esmer \& Dayi (2017) define it as a type of leadership that combines leadership potential with an entrepreneurial spirit. While Leitch \& Harrison (2018) have identified three different parameter positions of the relationship between entrepreneurship and leadership 1) entrepreneurship as a leadership style (leadership that has advantages); 2) entrepreneurial leadership as an entrepreneurial mindset (entrepreneurship that has advantages); and 3) entrepreneurial leadership is at the intersection of the two domains (Figure 1).

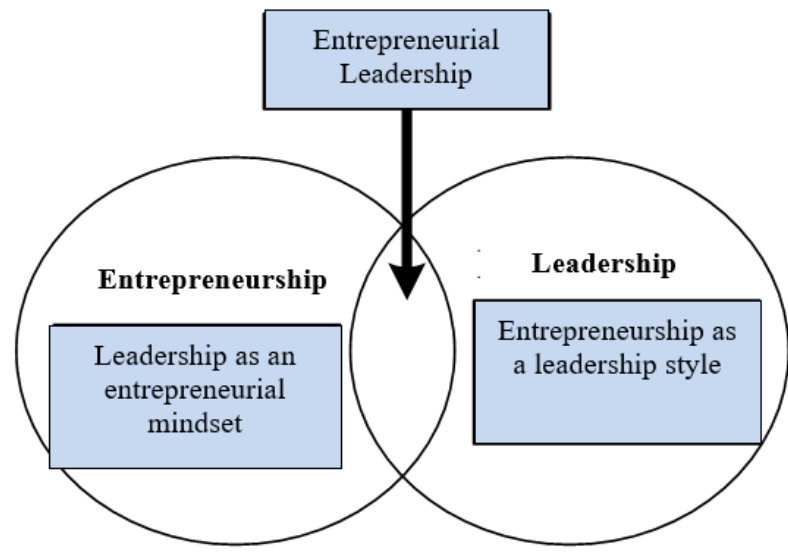

Source: Leitch \& Harrison (2018)

Figure 1 Leadership, entrepreneurship and entrepreneurial leadership

The behavioral characteristics of entrepreneurial leaders are risk taking, creative, passionate, visionary (Antonakis \& David, 2018), evaluating opportunities, being innovative, and productive (Esmer \& Dayi, 2017). Furthermore, Zijlstra (2019) in his research uses several dimensions related to entrepreneurial leadership, namely: risk taking, proactiveness, charisma, experimentation, vision, innovation, and creativity. Ranjan (2018) who reviewed many articles concluded the characteristics that entrepreneurial leaders might have such as performance-oriented, ambitious, informed, extra-visionary insight, foresight, trust-building, diplomatic, effective bidder, convincing, encouraging, inspirational, enthusiastic, team builder, improvement oriented, integrator, intellectual stimulation and positive attitude. According to Nguyen et al. (2021) which cited the statement of Gupta et al 


\section{JOURNAL OF MANAGEMENT, ACCOUNTING, GENERAL FINANCE AND INTERNATIONAL ECONOMIC ISSUES (MARGINAL) \\ VOLUME 1 ISSUE 1 (2021)}

(2004) that entrepreneurial leadership involves the organization and motivation of the company's operating system and employees to achieve the company's core values such as taking risks, capturing opportunities, innovating products and processes, creating competitive advantages, and enhancing dynamic competencies pursued by employers.

\subsection{Organizational Performance}

Organizational performance is considered as a measure of productivity, taking into account the participation of company employees (Oyemomi et al., 2016). Meanwhile, Jenatabadi (2015) defines organizational performance not referring to the results but to the process in which organizational performance is defined as all activities that support the achievement of organizational goals. Organizational performance can be measured for different hierarchical levels and can be assessed for individuals, groups, and the organization as a whole (Knies et al., 2016). Moreover, Antony and Bhattacharyya (2010) claim that organizational system performance is a complex interrelationship between six performance criteria: effectiveness, efficiency, quality, productivity, innovation and profitability.

At the individual level, Mathis et al. (2018) assessed performance based on the quality and quantity of results as well as effectiveness and efficiency as individual behaviors at work. Further, Luo et al. (2012) proposed an assessment of total organizational level performance with two performance indicators, namely, economic and operational performance indicators. To evaluate economic success from a financial and market perspective, financial measures such as revenue, sales, return on investment for shareholders, and other financial metrics are used to evaluate economic performance. Customer satisfaction and loyalty, corporate social capital, and competitive advantage resulting from competence and resources are some visible indicators of operational performance.

\section{RESEARCH METHOD}

The paper is prepared using the literature review method, which is sourced from textbooks and articles containing both concepts and empirical results. Articles obtained from sciencedirect, emerald, MDPI, and googlescholar. The organizational performance referred to in this paper includes all performance hierarchies, namely individuals, groups/teams, and the organization as a whole.

\section{RESULTS AND DISCUSSION}

\subsection{Research Result}

The selected articles are descriptive quantitative research, and the study of the articles taken is relevant to leadership and organizational performance.

Table 1 Summary of 3 articles

\begin{tabular}{|c|c|c|c|c|c|}
\hline $\begin{array}{l}\text { Author } \\
\text { (Year) }\end{array}$ & $\begin{array}{l}\text { Object of } \\
\text { research }\end{array}$ & $\begin{array}{l}\text { Theoretical } \\
\text { Framework }\end{array}$ & Method & $\begin{array}{c}\text { Participant } \\
\text { s }\end{array}$ & Key Findings \\
\hline $\begin{array}{l}\text { Samsudin } \\
\text { Wahab, } \\
\text { Adlan } \\
\text { Rahmat, } \\
\text { Mohd }\end{array}$ & $\begin{array}{l}\text { This study } \\
\text { examines the } \\
\text { leadership style } \\
\text { of academic } \\
\text { leaders at the }\end{array}$ & $\begin{array}{l}\text { Leadership } \\
\text { style, } \\
\text { Organizational } \\
\text { performance }\end{array}$ & $\begin{array}{l}\text { Correlatio } \\
\mathrm{n} \\
\text { Descriptive }\end{array}$ & $\begin{array}{l}\text { Five public } \\
\text { universities } \\
\text { in the Klang } \\
\text { Valley area. }\end{array}$ & $\begin{array}{l}\text { Most academic } \\
\text { leaders are } \\
\text { considered to } \\
\text { apply } \\
\text { transformationa }\end{array}$ \\
\hline
\end{tabular}




\begin{tabular}{|c|c|c|c|c|c|}
\hline $\begin{array}{l}\text { Yusof, } \\
\text { Badrisang } \\
\text { Mohamed } \\
(2016)\end{array}$ & $\begin{array}{l}\text { of Malaysia in } \\
\text { the Klang } \\
\text { Valley region. It } \\
\text { was found that } \\
\text { transformationa } \\
1 \text { leadership is } \\
\text { highly practiced } \\
\text { by most of the } \\
\text { academic } \\
\text { leaders at the } \\
\text { Malaysian State } \\
\text { University in } \\
\text { the Klang } \\
\text { Valley. }\end{array}$ & & & & $\begin{array}{l}\text { style because } \\
\text { employees can } \\
\text { easily share } \\
\text { knowledge } \\
\text { among } \\
\text { themselves } \\
\text { when } \\
\text { organizations } \\
\text { use } \\
\text { transformationa } \\
1 \quad \text { leadership } \\
\text { style. }\end{array}$ \\
\hline $\begin{array}{l}\text { Endi } \\
\text { Sarwoko } \\
(2020)\end{array}$ & $\begin{array}{l}\text { Understanding } \\
\text { the relationship } \\
\text { between } \\
\text { entrepreneurial } \\
\text { leadership and } \\
\text { innovation work } \\
\text { behavior, as } \\
\text { well as the role } \\
\text { of creative self- } \\
\text { efficacy as } \\
\text { mediating the } \\
\text { relationship } \\
\text { between } \\
\text { entrepreneurial } \\
\text { leadership and } \\
\text { innovation work } \\
\text { behavior }\end{array}$ & $\begin{array}{l}\text { Entrepreneuria } \\
1 \text { Leadership, } \\
\text { Social } \\
\text { Cognitive } \\
\text { Theory (SCT), } \\
\text { and Innovative } \\
\text { Work Behavior }\end{array}$ & $\begin{array}{l}\text { Single } \\
\text { source } \\
\text { method } \\
\text { from } \\
\text { employees }\end{array}$ & $\begin{array}{l}209 \\
\text { employees }\end{array}$ & $\begin{array}{l}\text { Entrepreneurial } \\
\text { leadership has a } \\
\text { positive effect } \\
\text { on innovative } \\
\text { work behavior. } \\
\text { In addition, } \\
\text { entrepreneurial } \\
\text { leadership } \\
\text { increases } \\
\text { creative self- } \\
\text { efficacy, which } \\
\text { in turn creative } \\
\text { self-efficacy } \\
\text { will encourage } \\
\text { innovative work } \\
\text { behavior }\end{array}$ \\
\hline $\begin{array}{l}\text { Khawaja } \\
\text { Fawad } \\
\text { Latif, Aqib } \\
\text { Nazeer, } \\
\text { Faisal } \\
\text { Shahzad, } \\
\text { Mohsin } \\
\text { Ullah, } \\
\text { Muhamma } \\
\text { d } \\
\text { Imranullah, } \\
\text { Umar } \\
\text { Farooq } \\
\text { Sahibzada } \\
\text { (2020) }\end{array}$ & $\begin{array}{l}\text { Describes a } \\
\text { knowledge- } \\
\text { based view } \\
\text { (KBV), the } \\
\text { study } \\
\text { investigates the } \\
\text { impact of } \\
\text { entrepreneurial } \\
\text { leadership (EL) } \\
\text { on knowledge } \\
\text { management } \\
\text { (KM) processes } \\
\text { and further } \\
\text { examines the } \\
\text { mediating role } \\
\text { of KM } \\
\text { processes on the } \\
\text { relationship }\end{array}$ & $\begin{array}{l}\text { Entrepreneuria } \\
1 \quad \text { leadership } \\
(\mathrm{EL}), \\
\text { Knowledge } \\
\text { management } \\
\text { process } \\
(\mathrm{KMPR}),\end{array}$ & $\begin{array}{l}\text { SMART- } \\
\text { PLS } \\
\text { structural } \\
\text { equation } \\
\text { modeling } \\
\text { tool. }\end{array}$ & $\begin{array}{l}304 \text { project } \\
\text { workers }\end{array}$ & $\begin{array}{l}\text { This study } \\
\text { found } \\
\text { significant } \\
\text { impact of EL on } \\
\text { KM and PS } \\
\text { processes. The } \\
\text { analysis also } \\
\text { reveals that the } \\
\text { KM process } \\
\text { significantly } \\
\text { influences } \\
\text { project success } \\
\text { while EL } \\
\text { influences PS } \\
\text { indirectly } \\
\text { through the KM } \\
\text { process. }\end{array}$ \\
\hline
\end{tabular}


between EL and

project success

(PS).

\subsection{Discussion}

\subsubsection{The Effect of Entrepreneurial Leadership on Organizational Performance on} Individual and Team Hierarchies

a. The Effect of Entrepreneurial Leadership on Employee Creativity

creativity is the creative thinking of employees based on their skills, qualifications and experience (Shafi et al., 2020). Competition in the global market and rapid technological transformation has made it difficult for organizations to develop creativity for innovation and modern business success (Huang et al., 2016). While previous research has recognized the importance of employee creativity in driving innovation in organizations (Shafi et al., 2020).

Entrepreneurial leadership is leadership behavior that encourages subordinates to identify and take advantage of entrepreneurial opportunities for value creation (Antonakis \& David, 2018) and thus aims at motivating employees to engage in creative activities (Cai et al., 2019). Entrepreneurial leaders inspire their employees to perform creative tasks in the workplace that involves recognizing and exploiting opportunities (Strobl et al., 2020). The results also show that there is a positive influence of entrepreneurial leadership on employee creativity (Mehmood et al., 2020) and also team creativity (Nguyen et al., 2021).

b. The Influence of Entrepreneurial Leadership on Employees' Innovative Work Behavior

Innovation is needed due to changes in the competitive business environment (Sawaean $\&$ Ali, 2020) and increasing business risks (Fontana \& Musa, 2017). Employee innovative behavior is a cognitive and motivational process directed at introducing, developing and implementing new ideas to provide useful and new solutions to complex and unclear problems (Afsar \& Masood, 2018). A number of existing literature recognizes the role of leadership in shaping individual attitudes and behaviors, including employee innovative behavior (Cai et al., 2019). Furthermore, research result by Bagheri (2017); Sarwoko (2020) and Iqbal et al. (2020) shows that entrepreneurial leadership has a significant effect on employee innovative behavior. The results of the research by Wibowo and Saptono (2018) who conducted research on educational organizations also showed that entrepreneurial leadership had an effect on the creative and innovative behavior of teachers.

\subsubsection{The Effect of Entrepreneurial Leadership on Organizational Performance on the Organization as a whole}

Luo et al. (2012) suggest measuring the performance of a business organization as a whole using two dimensions, namely the economic and operational dimensions. Further, Seo and Lee (2019) also use two components but with different terms, namely financial performance and non-financial performance. Nguyen et al (2021) who use non-financial performance as MSME performance by evaluating the company's ability towards sustainable development, product and service quality, reputation in the industry, overall customer satisfaction, and increasing sales volume over time where the results show that leadership Entrepreneurship has an indirect influence on the performance of MSMEs because 
entrepreneurial leadership will affect the dynamic ability of its employees to then have an impact on the performance of MSMEs. Dynamic capabilities are described as the capacity to integrate, develop, and reorganize the company's internal and external resources to deal with the rapidly changing business environment. Dynamic ability is a type of ability that can be acquired through experience. These dynamic capabilities enable managers to transform existing resources to develop new value creation strategies and contribute to creating, developing, and recombining other resources into a competitive advantage. According to the findings of Al Mamun et al (2018) that the characteristics of entrepreneurial leadership in the aspects of responsibility, accountability, and emotional intelligence show a significant positive effect on the performance of micro-enterprises.

Latif et al (2020) use project success as organizational performance where the measure of project success is seen from financial aspects (project completed within the allocated budget) and non-financial (project completed on time). The findings show that entrepreneurial leadership has a major influence on project success. This shows that projectbased organizations which are characterized by leadership orientation towards risk, challenge, and passion will have a higher propensity for successful projects. This further strengthens the assertion that leaders can benefit from entrepreneurial competence to deal with a highly volatile and competitive environment (Gupta et al., 2004).

Sarabi et al (2020) measure organizational performance by assessing the performance of subsidiaries using labor productivity, which is measured as total sales divided by the number of employees of the subsidiary. The results show that the entrepreneurial leadership of the subsidiary's CEO improves the performance of the subsidiary and that this relationship is strengthened by managerial discretion.

\section{CONCLUSION AND SUGGESTIONS}

Entrepreneurial leadership has a significant effect on the performance of individual employees and teams, especially in terms of creativity and innovative behavior. Entrepreneurial leadership also has a significant effect on overall organizational performance both in financial and non-financial dimensions.

\section{REFERENCES}

Afsar, B., \& Masood, M. (2018). Transformational Leadership, Creative Self-Efficacy, Trust in Supervisor, Uncertainty Avoidance, and Innovative Work Behavior of Nurses. Journal of Applied Behavioral Science, 54(1). https://doi.org/10.1177/0021886317711891

al Mamun, A., Ibrahim, M. D., Yusoff, M. N. H. bin, \& Fazal, S. A. (2018). Entrepreneurial leadership, performance, and sustainability of micro-enterprises in Malaysia. Sustainability (Switzerland), 10(5). https://doi.org/10.3390/su10051591

Antonakis, John., \& David, V. D. (2018). The nature of leadership development. In The nature of leadership.

Antony, J. P., \& Bhattacharyya, S. (2010). Measuring organizational performance and organizational excellence of SMEs - Part 2: An empirical study on SMEs in India. Measuring Business Excellence, 14(3). https://doi.org/10.1108/13683041011074209 


\section{JOURNAL OF MANAGEMENT, ACCOUNTING, GENERAL FINANCE AND INTERNATIONAL ECONOMIC ISSUES (MARGINAL) \\ VOLUME 1 ISSUE 1 (2021)}

Arifin, M., \& Gunawan, G. (2020). Entrepreneurial leadership models in the 21st century for vocational education. Utopia y Praxis Latinoamericana, 25(Extra 6). https://doi.org/10.5281/zenodo.3987599

Bagheri, A. (2017). The impact of entrepreneurial leadership on innovation work behavior and opportunity recognition in high-technology SMEs. Journal of High Technology Management Research, 28(2). https://doi.org/10.1016/j.hitech.2017.10.003

Bagheri, A., \& Harrison, C. (2020). Entrepreneurial leadership measurement: a multidimensional construct. Journal of Small Business and Enterprise Development, 27(4). https://doi.org/10.1108/JSBED-01-2019-0027

Cai, W., Lysova, E. I., Khapova, S. N., \& Bossink, B. A. G. (2019). Does Entrepreneurial Leadership Foster Creativity Among Employees and Teams? The Mediating Role of Creative Efficacy Beliefs. Journal of Business and Psychology, 34(2). https://doi.org/10.1007/s10869-018-9536-y

Esmer, Y., \& Dayi, F. (2017). Entrepreneurial Leadership: A Theoretical Framework. Journal of Mehmet Akif Ersoy, 4(2).

Fontana, A., \& Musa, S. (2017). The impact of entrepreneurial leadership on innovation management and its measurement validation. International Journal of Innovation Science, 9(1). https://doi.org/10.1108/IJIS-05-2016-0004

Gupta, V., MacMillan, I. C., \& Surie, G. (2004). Entrepreneurial leadership: Developing and measuring a cross-cultural construct. Journal of Business Venturing, 19(2). https://doi.org/10.1016/S0883-9026(03)00040-5

Harrison, C., Paul, S., \& Burnard, K. (2019). Entrepreneurial leadership: A Systematic Literature Review. International Review of Entrepreneurship, 14(2).

Harrison, R. T., \& Leitch, C. M. (2018). Research handbook on entrepreneurship and leadership. In Research Handbook on Entrepreneurship and Leadership. https://doi.org/10.4337/9781783473762

Huang, L., Krasikova, D. v., \& Liu, D. (2016). I can do it, so can you: The role of leader creative self-efficacy in facilitating follower creativity. Organizational Behavior and Human Decision Processes, 132. https://doi.org/10.1016/j.obhdp.2015.12.002

Iqbal, A., Nazir, T., \& Ahmad, M. S. (2020). Entrepreneurial leadership and employee innovative behavior: an examination through multiple theoretical lenses. European Journal of Innovation Management. https://doi.org/10.1108/EJIM-06-2020-0212

Jenatabadi, H. S. (2015). An Overview of Organizational Performance Index: Definitions and Measurements. SSRN Electronic Journal. https://doi.org/10.2139/ssrn.2599439

Knies, E., Jacobsen, C., \& Tummers, L. (2016). Leadership and organizational performance: State of the art and a research agenda. In The Routledge Companion to Leadership. https://doi.org/10.4324/9781315739854

Latif, K. F., Nazeer, A., Shahzad, F., Ullah, M., Imranullah, M., \& Sahibzada, U. F. (2020). Impact of entrepreneurial leadership on project success: mediating role of knowledge management processes. Leadership and Organization Development Journal, 41(2). https://doi.org/10.1108/LODJ-07-2019-0323

Li, C., Makhdoom, H. U. R., \& Asim, S. (2020). Impact of entrepreneurial leadership on innovative work behavior: Examining mediation and moderation mechanisms. Psychology Research and Behavior Management, 13. https://doi.org/10.2147/PRBM.S236876 
Luo, Y., Huang, Y., \& Wang, S. L. (2012). Guanxi and organizational performance: A metaanalysis. Management and Organization Review, 8(1). https://doi.org/10.1111/j.17408784.2011.00273.x

Lussier, R. N., \& Hendon, J. R. (2019). Human Resource Management - Functions, Applications, and skill development. In Sage Publications Ltd. (Vol. 3, Issue 5).

Mathis, A., Mamidanna, P., Cury, K. M., Abe, T., Murthy, V. N., Mathis, M. W., \& Bethge, M. (2018). DeepLabCut: markerless pose estimation of user-defined body parts with deep learning. Nature Neuroscience, 21(9). https://doi.org/10.1038/s41593-018-0209$\mathrm{y}$

Mehmood, M. S., Jian, Z., \& Akram, U. (2020). Be so creative they can't ignore you! How can entrepreneurial leader enhance the employee creativity? Thinking Skills and Creativity, 38. https://doi.org/10.1016/j.tsc.2020.100721

Nguyen, P. v., Huynh, H. T. N., Lam, L. N. H., Le, T. B., \& Nguyen, N. H. X. (2021). The impact of entrepreneurial leadership on SMEs' performance: the mediating effects of organizational factors. Heliyon, 7(6). https://doi.org/10.1016/j.heliyon.2021.e07326

Oyemomi, O., Liu, S., Neaga, I., \& Alkhuraiji, A. (2016). How knowledge sharing and business process contribute to organizational performance: Using the fsQCA approach. Journal of Business Research, 69(11). https://doi.org/10.1016/j.jbusres.2016.04.116

Paladan, N. N. (2015). Transformational Leadership: The Emerging Leadership Style of Successful Entrepreneurs. Journal of Literature and Art Studies, 5(1). https://doi.org/10.17265/2159-5836/2015.01.008

Ranjan, S. (2018). Entrepreneurial Leadership: A Review of Measures, Antecedents, Outcomes and Moderators. Asian Social Science, 14(12). https://doi.org/10.5539/ass.v14n12p104

Robbins, S. P., \& Judge, T. A. (2017). Organizational Behavior 17th Ed (17th ed.). Pearson.

Rutan, S. (2019). Entrepreneurial Leadership: An Emerging Theory. Staff Publications University of Guelph. Available at Https://First.Fanshawec.ca/Ir_staffpublications/1.

Ruvio, A., Rosenblatt, Z., \& Hertz-Lazarowitz, R. (2010). Entrepreneurial leadership vision in nonprofit vs. for-profit organizations. Leadership Quarterly, 21(1). https://doi.org/10.1016/j.leaqua.2009.10.011

Sani, A., Ekowati, V. M., Wekke, I. S., \& Idris, I. (2018). Respective contribution of entrepreneurial leadership through organizational citizenship behaviour in creating employee's performance. Academy of Entrepreneurship Journal, 24(4).

Sarabi, A., Froese, F. J., Chng, D. H. M., \& Meyer, K. E. (2020). Entrepreneurial leadership and MNE subsidiary performance: The moderating role of subsidiary context. International Business Review, 29(3). https://doi.org/10.1016/j.ibusrev.2020.101672

Sarwoko, E. (2020). Entrepreneurial Leadership and Innovative Work Behavior: The Role of Creative Self-efficacy. Journal of Economics, Business, \& Accountancy Ventura, 23(2). https://doi.org/10.14414/jebav.v23i2.2282

Sawaean, F. A. A., \& Ali, K. A. M. (2020). The impact of entrepreneurial leadership and learning orientation on organizational performance of SMEs: The mediating role of innovation capacity. Management Science Letters, 10(2). https://doi.org/10.5267/j.msl.2019.8.033

Seo, Y. W., \& Lee, Y. H. (2019). Effects of internal and external factors on business performance of start-ups in South Korea: The engine of new market dynamics. 


\section{JOURNAL OF MANAGEMENT, ACCOUNTING, GENERAL FINANCE AND INTERNATIONAL ECONOMIC ISSUES \\ (MARGINAL) \\ VOLUME 1 ISSUE 1 (2021)}

International Journal of Engineering Business Management, 11. https://doi.org/10.1177/1847979018824231

Shafi, M., Zoya, Lei, Z., Song, X., \& Sarker, M. N. I. (2020). The effects of transformational leadership on employee creativity: Moderating role of intrinsic motivation. Asia Pacific Management Review, 25(3). https://doi.org/10.1016/j.apmrv.2019.12.002

Strobl, A., Bauer, F., \& Matzler, K. (2020). The impact of industry-wide and target market environmental hostility on entrepreneurial leadership in mergers and acquisitions. Journal of World Business, 55(2). https://doi.org/10.1016/j.jwb.2018.03.002

Wahab, S., Rahmat, A., Yusof, M. S., \& Mohamed, B. (2016). Organization Performance and Leadership Style: Issues in Education Service. Procedia - Social and Behavioral Sciences, 224. https://doi.org/10.1016/j.sbspro.2016.05.447

Wibowo, A., \& Saptono, A. (2018). Does entrepreneurial leadership impact on creativity and innovation of elementary teachers? Journal of Entrepreneurship Education, 21(2).

Zijlstra, P. (2019). Entrepreneurial Leadership - When is Entrepreneurial Leadership most effective? In The Grants Register 2020. 